\title{
Commitment versus Discretion in a Political Economy Model of Fiscal and Monetary Policy Interaction
}

\author{
David S. Miller \\ Federal Reserve Board*
}

\begin{abstract}
Price commitment results in lower welfare. I explore the consequences of price commitment by pairing an independent monetary authority issuing nominal bonds with a fiscal authority whose endogenous spending decisions are determined by a political economy model. Without price commitment, nominal bonds are backed by a new form of endogenous commitment that overcomes time inconsistency to make tax smoothing possible. With price commitment, nominal bonds will be used for both tax smoothing and wasteful spending. Price commitment eliminates monetary control over fiscal decisions. I show that the combination observed in advanced economies of a politically distorted fiscal authority and an independent monetary authority with nominal bonds and without price commitment is the solution to a constrained mechanism design problem that overcomes time inconsistency and results in the highest welfare.
\end{abstract}

JEL classification: E52, E58, E62

Keywords: Price Commitment, Monetary Policy, Monetary Fiscal Policy Interaction, Time Inconsistency

\footnotetext{
*E-mail: david.s.miller@frb.gov. The views expressed in this paper are those of the author and not necessarily those of the Federal Reserve Board or of the Federal Reserve System. The author thanks Matthias Doepke, Martin Eichenbaum, Mirko Wiederholt, Northwestern's Macro Presentations, Nicolas Ziebarth, Chris Vickers, Luca Dedola, Marco Bassetto, Andre Kurmann, the participants at the 2013 System Committee on Macroeconomics.
} 


\section{Introduction}

Kydland and Prescott (1977) and Barro and Gordon (1983) ${ }^{1}$ find that price commitment results in higher welfare in models with benevolent fiscal and monetary authorities and nominal bonds. I find the opposite: price commitment leads to lower welfare. I change the benevolent fiscal authority to one microfounded in a political economy model. This makes fiscal decisions endogenous to the environment and nominal bond level. If the monetary authority commits to a price level, the politically distorted fiscal authority is free to spend with impunity leading to welfare loss.

In models with benevolent fiscal and monetary authorities, price commitment leads to welfare gains because it overcomes the time inconsistency problem of nominal debt: a benevolent monetary authority with discretionary policy will inflate away the real value of nominal debt at the start of every period, allowing the benevolent fiscal authority to set taxes to the minimum. Consumers anticipate this inflation and won't hold bonds because their real value will evaporate. Thus nominal bonds will not exist. Price commitment eliminates the benevolent monetary authority's ability to inflate; equivalently it turns nominal bonds into indexed bonds. The benevolent fiscal authority can then increase welfare by using bonds to smooth taxes as shown in Barro (1979).

The benefit of price commitment is stark: no bonds with discretionary policy versus the benevolent optimal amount of bonds with price commitment. I show in this paper that a politically distorted fiscal authority is able to issue nominal debt without price commitment. The benefit of price commitment in this situation is not as stark: bonds for tax smoothing with discretionary policy versus bonds for tax smoothing and wasteful spending with price commitment. Additionally, the cost of price commitment will be positive: price commitment lowers welfare by allowing a politically distorted fiscal authority to issue bonds to fund wasteful spending that will require higher taxes in the future to pay off.

In the course of proving the new result about price commitment, I provide new answers to two other questions of monetary economics: why do governments issue nominal debt, and why is an independent central bank desirable. The analysis shows that nominal debt provides a method for an independent central bank to discipline a

\footnotetext{
${ }^{1}$ These papers deal with the time inconsistency problem of nominal debt in models with a Phillips curve rather than directly through the government's budget constraint. The time inconsistency problem is identical.
} 
politically distorted fiscal authority. In return, the politically distorted fiscal authority overcomes the time inconsistency of nominal debt by anchoring expectations that the central bank won't monetize the debt. I show that pairing a politically distorted fiscal authority and an independent monetary authority is efficient. It can be viewed as the result of a constrained mechanism design problem that seeks to overcome time inconsistency while minimizing any political distortion.

The divergence between the goals of the politically distorted fiscal authority and the independent, benevolent monetary authority enables the monetary authority to better fulfill its objectives than if both it and the fiscal authority were benevolent. The non-optimality of coordination is similar to the benefits Rogoff (1985b) finds a conservative central banker provides to an economy by reducing inflation expectations.2

I use the political economy model of Battaglini and Coate (2008) to rationalize fiscal decisions with microfoundations. The government tries to maximize the utility of a subset of the citizens instead of maximizing the utility of the society as a whole. A politically distorted fiscal authority will, when it has little debt, spend on private transfers to its coalition rather than on public goods.

An independent benevolent monetary authority knows that inflating away the real value of nominal debt will give the politically distorted fiscal authority budgetary freedom to spend revenue on private transfers rather than on public goods. Maintaining a positive level of nominal debt constrains wasteful spending, but if debt is too high it requires high distortionary taxes to pay off. Thus a form of endogenous price commitment arises: the independent monetary authority will inflate away some of the debt, so that taxes will be lower, but not all of the debt. The remaining debt will be enough to prevent the distorted fiscal authority from wasting revenue on transfers.

Endogenous commitment allows the independent monetary authority to control the spending decisions of the politically distorted fiscal authority. This commitment has two beneficial effects: it alleviates time inconsistency and it limits the power of the political distortion. Pairing a politically distorted fiscal authority with an independent monetary authority allows the fiscal authority is able to issue nominal bonds. The bonds increase overall welfare because they enable tax smoothing.

Forcing the central bank to commit to a price level in advance increases the amount

\footnotetext{
${ }^{2}$ In this paper the central bank is not made exogenously conservative. The distortion happens on the fiscal side due to the endogenous self-interest of the fiscal authority.
} 
of nominal bonds that can be issued. This extra revenue will be spent at the discretion of the politically distorted fiscal authority. The benefits of the extra revenue will not outweigh the future increases in taxes that will be necessary to pay off the bonds. Welfare will be lower because of these higher taxes.

If control of the monetary authority is captured by the politically distorted fiscal authority the economy will be subject to the time inconsistency problem as before. The government won't be able to issue any nominal debt. Thus central bank independence is key to separate the (benevolent) goals of the monetary authority from the (politically distorted) goals of the fiscal authority.

A monetary union such as the European Union is another form of monetary and fiscal interaction. My paper predicts that a union of homogenous countries can make previously non-trustworthy central banks trustworthy. Countries in such a union will be able to sustain nominal bonds with the same endogenous commitment described previously. Trouble arises when the monetary union is composed of heterogeneous countries. For example, if the central bank cares only about the large countries in the union, the small countries will behave as if they have price commitment. This explains the behavior of Greece. It took advantage of the Eurozone by issuing bonds to fund transfers to the governing coalition. When a bad shock hit, Greece had to tax at a punitive rate to fund its previous profligacy.

The rest of the paper provides the model and specific comparisons of fiscal policy and price commitment. In Section 2 I review the relevant literature on the subject. In Section 3, following the analysis above, I show a benevolent fiscal authority is unable to issue nominal bonds while a self-interested fiscal authority is able to do so. Welfare is higher in the latter situation since the bonds may be used for tax smoothing. I add price commitment to the monetary authority so nominal debt becomes equivalent to indexed debt. A benevolent fiscal authority can now use bonds to smooth taxes while a self-interested fiscal authority can issue more bonds to fund larger direct transfers. In the former situation, society is better off with commitment, in the latter situation it is not. In Section 4 I show that the combination of a self-interested fiscal authority, a benevolent monetary authority and nominal bonds is the welfare maximizing setup for monetary and fiscal policy. Section 5 extends the model to explore monetary unions and draws parallels to the troubles afflicting the European Union. And finally, Section 6 concludes. 


\section{Literature Review}

The benefit of government debt as a way to smooth taxation is originally seen in Barro (1979). Debt provides an intertemporal link between good times and bad times and allows tax rates to remain constant despite variable economic conditions. This will be the positive use of bonds in this model. The revenue raised from bonds will be available for tax smoothing, as well as other more wasteful uses.

Time inconsistency prevents the use of nominal bonds. It is examined in Kydland and Prescott (1977). Time inconsistency specifically of joint monetary and fiscal policy is investigated in Lucas and Stokey (1983) and Barro and Gordon (1983). These papers show that the lump-sum nature of the inflation tax strictly dominates any other revenue generating tax instrument. The availability of the inflation tax creates an incentive for the monetary authority to inflate and thus the time inconsistency problem. I duplicate this result before the introduction of a political distortion. After its introduction, the time inconsistency problem is partially solved.

The benefit of price level commitment as a method of overcoming time inconsistency is investigated in numerous papers. A good overview of results is found in Chari et al. (1991). Price level commitment is in the form of a Ramsey plan: the central bank can choose the price level for all periods in advance ignoring time inconsistency. Price level commitment is shown to increase utility by supporting bonds to smooth taxes. While this is still a use of bond revenue, I show that price level commitment can lead to decreased utility by leading to wasteful spending by the fiscal authority. More bonds requires higher taxes in the future and thus lower overall utility.

Overcoming time inconsistency without explicit exogenous commitment is investigated for various functional forms of utility in Albanesi et al. (2001), Alvarez et al. (2004), and Díaz-Giménez et al. (2008). These papers balance the direct utility costs of inflation with the budget benefits. Persson et al. (1987) starts a literature that uses the term structure of nominal debt to the same effect. I mitigate time inconsistency in a new way founded in the differing goals of monetary and fiscal policy. Time inconsistency still dominates until the utility functions of the two are separated.

The idea that differing utility functions can result in an overall better outcome is the mechanism in Rogoff (1985a). He investigates how differing utility functions can be beneficial in an international context. Countries can cooperate by matching monetary policy moves and hence holding exchange rates constant. This gives a greater 
incentive to inflate which figures into consumers' expectations of inflation and leads to actual inflation. If the countries compete, monetary policy is constrained because the negative effects of exchange rate fluctuations dominate gains from inflation. I use a similar dynamic between utility functions to mitigate time inconsistency albeit between monetary and fiscal authorities rather than countries. His result that cooperation leads to worse outcomes is similar to the result I obtain.

For monetary unions, Chari and Kehoe (2008) analyze behavior where the individual members attempt to maximize utility functions that are separate, and different, from the utility function of the entire union. This leads to suboptimal outcomes without methods for disciplining members. My paper differs by explicitly microfounding fiscal and monetary decisions, through studying a single country rather than a monetary union, and by the tools available to the fiscal authority.

Martin (2011) investigates what microfounding money in the method of Lagos and Wright 2005) does to price level commitment. He finds that price level commitment no longer has significant effects. I use the cashless limit where money doesn't appear directly. A version with a cash-in-advance constraint as in Lucas and Stokey (1987) doesn't change results significantly.

Another analysis of monetary policy is found in Rogoff (1985b). This work sees the advantage in monetary policy having a different utility function from the consumer. By making the central banker more inflation averse than consumers, consumers limit their inflation expectations. An overview of the benefits of a conservative central banker is found in Fischer (1995). Adam and Billi (2008) present a more modern model with independent fiscal and monetary policies built around a conservative central banker. I don't rely on a conservative central banker (which is equivalent to a form of price commitment). I microfound the split in utility functions between the monetary and fiscal sides of the economy. The difference is not from exogenous preferences (as with a more conservative central banker) but directly from the effect of political distortion on fiscal policy. Having distinct utility functions for monetary and fiscal policies provides a similar benefit in limiting consumers' inflation expectations.

The fiscal policy model used in my paper, and its political distortion, is adapted from a series of papers Battaglini and Coate (2008), and Barseghyan et al. (2013). They use an infinite period model with a political distortion from Baron and Ferejohn (1989) in which a subgroup of citizens controls fiscal policy. There is no monetary policy so their bonds are indexed. They show that this model results in debt dynam- 
ics that match the broad outlines of modern U.S debt dynamics. Azzimonti et al. (2010) uses the basic model to analyze the welfare implications of a balanced budget amendment.

Bohn (1988) explains the role of nominal debt as a hedging device against unexpected shocks. In a recession the government would like to increase spending but would prefer not to raise taxes. Inflation provides real revenues without the distorting effects of taxes. This explains the time inconsistency problem as one of balancing the benefit of hedging against the cost of inflation. Nominal bonds allow hedging but they lead to inflation. My paper endogenizes this result by endogenizing bond choices. Nominal debt is used because it affords the monetary authority limited control over the fiscal authority. This restricts the extent to which the political distortion affects fiscal choices.

The idea that fiscal and monetary policy interact through the government budget constraint is found in Sargent and Wallace (1981). To make the budget constraint hold, the fiscal authority can force the hand of the monetary authority to inflate away bonds or the monetary authority can force the fiscal side to increase revenues. The dynamic is magnified in my paper. The choices of fiscal policy are not static; the amount of spending is a function of debt and current conditions. Monetary choices will constrain the fiscal side by limiting its budget constraint through price level manipulations.

A considerable amount of study of monetary and fiscal interactions has centered on the Fiscal Theory of the Price Level as seen in Leeper (1991). It proposes that the fiscal authority can set the price level by changing the present value of expected future tax revenue and thus how much money consumers expect to be repaid for their bonds. For an overview see Bassetto (2008) or Christiano and Fitzgerald (2000). The default timing I examine, monetary policy setting the price level before the fiscal authority sets tax revenue is roughly analogous to Leeper's active monetary, passive fiscal regime. The other possibility is fiscal policy moving before monetary policy. I find that a full Fiscal Theory of the Price Level type result requires an explicit fiscal commitment as in Schmitt-Grohé and Uribe (2000). 


\section{The Model}

Nominal government debt, when sustainable, links periods. Fiscal policy consists of setting taxes, expenditure on a public good, direct transfers to citizens, and nominal bond issuance. A real shock determines wages (and the distortion due to taxes) at the beginning of every period. After the shock, the monetary authority sets the price level, then the fiscal authority chooses its policy.

\subsection{Consumers}

There are $n$ identical consumers, indexed by $i$ when necessary. A consumer's per period utility function is

$$
u(c, g, l)=c+A \log (g)-\frac{l^{1+1 / \epsilon}}{\epsilon+1}
$$

and they seek to maximize $U=\sum_{t} \beta^{t} u\left(c_{t}, g_{t}, l_{t}\right)$ where $c$ is a consumption good, $g$ is government spending on a public good, $l$ is labor, and $\beta$ the discount rate. The parameter $\epsilon>0$ is the Frisch elasticity of labor. Variables without subscripts will refer to period $t$ while variables with a prime refer to variables in period $t+1$

A representative consumer $i$ in period $t$ faces the budget constraint

$$
c+q B_{n}^{\prime} \leq w l(1-\tau)+\frac{B_{n}}{P(B)}+T_{i}
$$

The consumer can consume $c$ or purchase nominal bonds $B_{n}^{\prime}=\frac{B^{\prime}}{n}$. All consumers will hold an identical amount of bonds $B_{n}^{\prime}$, so the total amount of bonds is $B^{\prime}=n B_{n}^{\prime}$. The consumer's income consists of labor income at wage $w$ that is taxed by the government at distortionary tax rate $0 \leq \tau \leq 1$ and direct transfers $T_{i}>0$ from the government. $P(B)^{3}$ is the price level determined by the monetary authority at the start of the period. The price level is a function solely of the amount of bonds extant as bonds are the only variable affected by changes. For simplicity the price level in the current period will at times be abbreviated $P=P(B)$ and the price level in the next period as $P^{\prime}=P\left(B^{\prime}\right)$.

\footnotetext{
${ }^{3}$ The price level is described as a function of $B$ rather than $B_{n}$ because it is a choice of the monetary authority rather than consumer. Results are identical for $P\left(B_{n}\right)$ with a few extra multiplications by $n$.
} 
Combining these equations I derive the equilibrium bond price

$$
q=\beta E_{w^{\prime}}\left[\frac{1}{P^{\prime}}\right]
$$

where the expectation is over realizations of the wage $w^{\prime}$ in the next period. A consumer's utility is defined entirely by the government's choices of taxation $\tau$ and public good spending $g$. The simplified indirect utility function is

$$
W(\tau, g)=\frac{\epsilon^{\epsilon}(w(1-\tau))^{\epsilon+1}}{\epsilon+1}+A \log (g)
$$

\section{$3.2 \quad$ Firms}

The representative firm has a linear production technology

$$
z=w l
$$

used to produce an intermediate good $z$ at wage $w$ with labor $l$. At the beginning of every period a technology shock hits the economy such that wages $w \in\left\{w_{l}, w_{h}\right\}$ where $w_{l}<w_{h}$. The probability that $w=w_{h}$ is $\pi$, the probability that $w=w_{l}$ is $1-\pi$.

The intermediate good $z$ is split costlessly between the consumption good $c$ and the public good $g$ such that

$$
c+g=z \text {. }
$$

This defines the per period resource constraint

$$
c+g \leq w l
$$

\subsection{Government}

The government controls fiscal policy. Raising revenue is possible via a distortionary labor $\operatorname{tax} \tau$ and selling nominal bonds $B$. A positive bond level $B$ means the government is in debt hence owes money to consumers. Revenue can be spent on a public good $g$ that benefits all $n$ citizens or on strictly positive transfer payments $T_{i}$ that benefit individuals. The revenue raised via taxation must be sufficient to cover bond payments of $\frac{B}{P}$. 
The budget constraint is

$$
g+\sum_{i} T_{i}+\frac{B}{P} \leq \operatorname{Rev}(\tau)+q B^{\prime}
$$

where

$$
\operatorname{Rev}(\tau)=n \tau w(\epsilon w(1-\tau))^{\epsilon}
$$

is the total tax revenue raised by the distortionary labor tax on all $n$ consumers.

Define the budget surplus before transfers as

$$
S\left(\tau, g, B^{\prime} ; \frac{B}{P}\right)=\operatorname{Rev}(\tau)+q B^{\prime}-g-\frac{B}{P} .
$$

The surplus must be large enough to pay for any transfers hence $S\left(\tau, g, B^{\prime} ; B / P\right) \geq$ $\sum_{i} T_{i}$. Transfers themselves must be strictly positive: $\forall i T_{i} \geq 0$.

There are endogenous limits to amount of bonds the government can issue. The upper bound on debt is because the government cannot issue more bonds than it would, in the case of a negative shock, have tax revenue to pay back. Define $\bar{B}$ as $\bar{B}=\max _{\tau} \operatorname{Rev}_{l}(\tau)$.

The lower bound on debt is the amount of bonds the government would hold such that the revenue from the bonds would be sufficient to fund optimal public good spending without any tax revenue. This maximum amount of public good spending is $\frac{n A}{g}=1$ Since the public good has declining marginal benefit there's no gain to public good spending that that results in lower utility than keeping the revenue in consumers' pockets. Define $\underline{B}$ as $\underline{B}=-n A$ the level of bonds where one more unit of government spending has the same marginal utility as individual consumption. This is the Samuelson level of bonds where the marginal cost of revenue is equal to the marginal benefit of the public good.

There may be a continuum of bond amounts $B$ that result in the same bond revenue $q B$. Issuing bonds above a level can result in the expected price level increasing to perfectly offset the amount of revenue the new bonds would gain. For example the pricing function:

$$
P= \begin{cases}1, & \text { if } B<1 \\ B, & \text { if } B \geq 1\end{cases}
$$

results in identical revenue for all bond levels greater than 1. 


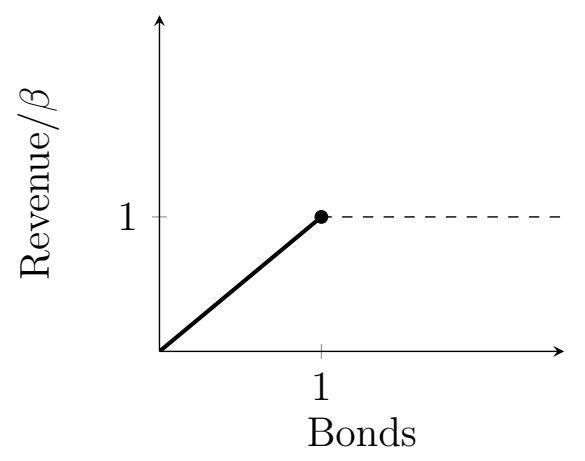

Figure 1: Illustration of Revenue Equivalence for Bonds $\geq 1$

Two equilibriums with identical bond revenue will be identical with regards to all other variables. To simplify discussion I assume the government issues the minimum amount of bonds necessary for a given level of revenue. That is the government chooses the bond level $B$

$$
\forall k, B=\min _{B}\{B: q B=k\}
$$

\subsubsection{Self-Interested Fiscal Policy}

When indicated, fiscal policy decisions will be made by a subgroup of the citizenry interested in maximizing their own utilities. I term this self-interested fiscal policy to contrast it from the choices of benevolent fiscal policy which attempts to maximize the utility of all citizens.

Following the political system laid out in Battaglini and Coate (2008) who extend the political economy model of Baron and Ferejohn (1989), citizens vote each period to decide that period's fiscal policy $\left\{\tau, g, B, T_{i}\right\}$. The power to propose a choice of fiscal policy is randomly assigned to one citizen. A proposal is enacted if $m<n$ citizens vote for it. If a proposal fails, the power to propose is randomly assigned to a different citizen. There can be a maximum of $T$ proposal rounds after which a dictator is appointed. The dictator chooses policies unilaterally with the constraint that all transfers must be equal.

I focus on a symmetric Markov-perfect equilibrium. These are proposals that are accepted in each round; thus we can examine only the first proposal. In order for this to happen, the proposal must make the members of the $m$ coalition as well off as the 
expectation of the next proposal. The expectation arises from the random assignment of proposal powers and thus the randomness of being included in the next proposer's $m$ coalition. In practical terms, proposers will select fiscal instruments to maximize the utility of the $m$ citizens in the coalition without care for non-coalition citizens. This is in contrast to benevolent choices which can be thought of as the case where $m=n$.

A fiscal policy proposal defines the fiscal policy for a single period. The next period a new proposer is randomly selected and the process begins anew. Fiscal policy commitment over periods is not allowed.

\subsection{Monetary Authority}

The monetary authority chooses price level $P$ to maximize aggregate welfare. Inflation is costless in this model. The model utilizes timing akin to a Stackelberg game with the monetary authority as leader and the government as follower. The monetary authority chooses $P$ after the shock in each period. Thus monetary policy controls the real value of government debt which is equivalent to consumer wealth.

The choice of timing is deliberate. Briefly, under the alternative timing the fiscal authority won't raise any revenue for bond repayment via distortionary taxes because this will force the monetary authority to inflate away the value of any bonds that are issued. Inflation's lump sum tax nature is preferred to the distortionary labor tax. The result is that no nominal bonds are possible to any fiscal authority This does not resemble the real world.

\section{Model Analysis}

Analysis of the model follows the outline provided by the proofs of the propositions. First, I show that the addition of micro foundations to the fiscal authority partial solves the time inconsistency problem that prevents the use of nominal bonds.

Proposition 1 A self-interested fiscal authority is able to support nominal bonds while a benevolent fiscal authority is unable to do so.

\footnotetext{
${ }^{4}$ For a more complete explanation see the brief note that concludes the appendix.
} 
To prove Proposition 1 I show that a benevolent fiscal authority paired with a monetary authority will be unable to raise revenue by issuing nominal bonds. I then change the benevolent fiscal authority to a self-interested fiscal authority and show that this combination is able to raise revenue by issuing nominal bonds.

I now compare the welfare effects of price level commitment to the alternative of discretionary monetary policy.

Definition 1 Price level commitment is defined as $P=k$ for some $k$ for all period 5 . Discretionary monetary policy is defined as $P=P(B)$ at the start of every period.

Proposition 2 Price level commitment by a monetary authority with a self-interested fiscal authority and nominal bonds results in lower welfare than discretionary monetary policy.

To prove Proposition 2 I show that discretionary monetary policy with a selfinterested fiscal authority leads to the lowest taxes and highest public good spending possible. Price level commitment is strictly worse.

\subsection{The Benevolent Fiscal Authority's Problem}

A benevolent fiscal authority tries to maximize total welfare. Since consumers are identical this is equivalent to maximizing the utility of a single consumer. The benevolent fiscal authority's problem can be written as

$$
\begin{array}{cc}
\max _{\tau, g, B^{\prime},\left\{T_{i}\right\}_{1}^{n}} & W(\tau, g)+\frac{\sum_{i} T_{i}}{n}+\beta\left[\pi v_{H}\left(B^{\prime}\right)+(1-\pi) v_{L}\left(B^{\prime}\right)\right] \\
\text { s.t. } & T_{i} \geq 0 \forall i, S\left(\tau, g, B^{\prime} ; \frac{B}{P}\right) \geq \sum_{i}^{n} T_{i}, B^{\prime} \in[\underline{B}, \bar{B}], \\
& \forall k B^{\prime}=\min \left\{B^{\prime}: q B^{\prime}=k\right\}
\end{array}
$$

\footnotetext{
${ }^{5}$ The requirement that the price level is identical for all periods is unnecessary for what follows. Proposition 2 will hold for price level commitment of any length.
} 
The monetary authority chooses $P$ to maximize welfare

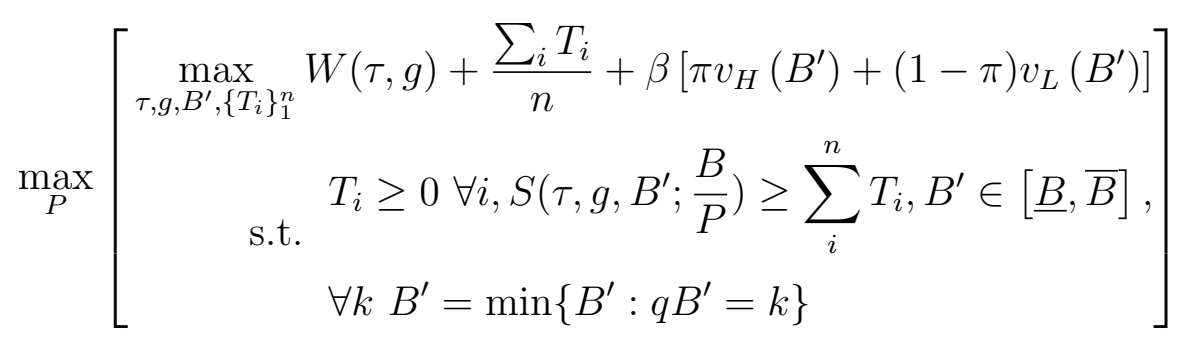

Combining these two problems and simplifying we can write this recursively for a given bond level $B$ as

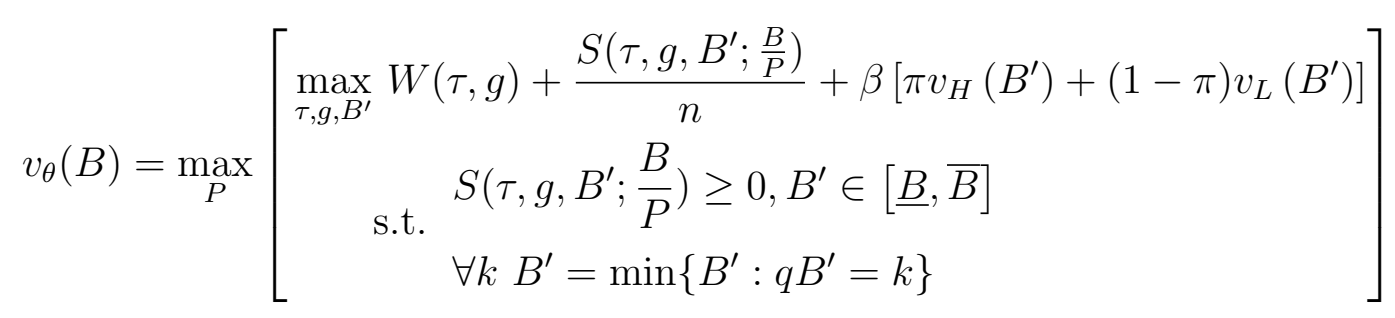

where subscript $\theta \in\{h, l\}$ denotes the realization of the wage shock. The first constraint is that surplus must be weakly positive. Any surplus will be distributed to citizens as a transfer, each citizen receiving an equal share. The second constraint keeps the level of bonds between the two boundary values as explained previously. The third constraint selects the minimal $B$ in every level set of revenue.

The first order conditions of this problem are

$$
\begin{aligned}
& \frac{1-\tau}{1-\tau(1+\epsilon)}=\frac{n A}{g} \\
& \frac{1-\tau}{1-\tau(1+\epsilon)}=-n \beta\left[\pi v_{H}^{\prime}\left(B^{\prime}\right)+(1-\pi) v_{L}^{\prime}\left(B^{\prime}\right)\right]
\end{aligned}
$$

The expression $\frac{1-\tau}{1-\tau(1+\epsilon)}$ is the marginal distortionary cost of non-linear taxation. The first equation equates the marginal cost of raising an additional unit of revenue with the marginal benefit of spending that revenue on public goods. The second equation equates the marginal cost of raising an additional unit of revenue via taxation with the marginal cost of raising the revenue by issuing bonds (and thus smoothing the cost of taxation by pushing it into the future). 
The monetary authority's response function $P(B)$ is

$$
P(B)= \begin{cases}\frac{\underline{B}}{\bar{B}}, & \text { if } B<0 \\ {[1, \infty),} & \text { if } B=0 \\ \infty, & \text { if } B>0\end{cases}
$$

If there are a positive amount of nominal bonds, the monetary authority erases the real value of the bonds by setting the price level to infinity. This allows the benevolent fiscal authority to lower taxes since it no longer needs the revenue to pay off bonds. If there are no nominal bonds, the price level is indeterminate as it only affects the real value of the nominal bonds. If there are negative bonds (the government is owed money), the monetary authority will deflate causing the real value of society's debt to equate to the Samuelson level $\underline{B}$ where all future taxes are zero and government spending is constant.

Claim 2 The benevolent fiscal authority's solution is to issue 0 bonds that raise 0 revenue in every period.

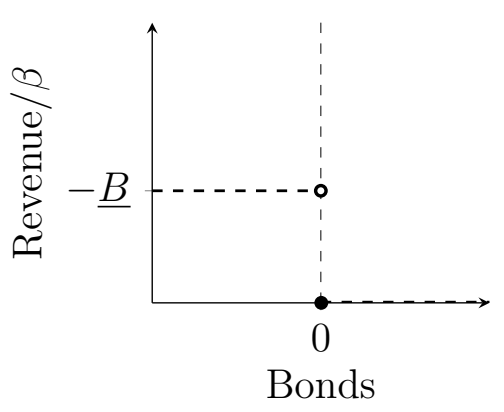

Figure 2: Revenue with a Benevolent Fiscal Authority

The behavior of the monetary authority drives the result. This is the problem of a monetary authority without commitment. The benevolent fiscal authority is unable to issue bonds because the monetary authority will erase their real value every period. Thus there will be no tax smoothing.

As shown by Aiyagari et al. (2002) and Battaglini and Coate (2008), the fiscal authority would optimally have a negative level of bonds. This is a way of using linear taxation (bond remittances) rather than distortionary labor taxation. In those 
models the government accumulates a stockpile of real bonds over time. In this model the government is unable to do so because of the monetary authority: all bonds must be raised in a single period. In that period, distortionary taxes would be extremely high to fund the bond purchases. This would have a tremendous negative welfare impact and thus may not be possible.

\subsection{The Self-Interested Fiscal Authority's Problem}

A proposer of fiscal policies has to get $m>\frac{n}{2}$ votes for the proposal. Counting the proposer's own vote, $m-1$ other votes are needed. In order to get those votes, the proposer's policies attempt to maximize the utility of the $m-1$ randomly chosen citizens as well as his own. The self-interested fiscal authority's problem is

$$
\begin{array}{cc}
\max _{\tau, g, B^{\prime},\left\{T_{i}\right\}_{1}^{n}} & W(\tau, g)+\frac{\sum_{i} T_{i}}{m}+\beta\left[\pi v_{H}\left(B^{\prime}\right)+(1-\pi) v_{L}\left(B^{\prime}\right)\right] \\
\text { s.t. } & T_{i} \geq 0 \forall i, S\left(\tau, g, B^{\prime} ; \frac{B}{P}\right) \geq \sum_{i}^{n} T_{i}, B^{\prime} \in[\underline{B}, \bar{B}], \\
& \forall k B^{\prime}=\min \left\{B^{\prime}: q B^{\prime}=k\right\}
\end{array}
$$

The monetary authority chooses $P$ to maximize welfare

$$
\max _{P}\left[\begin{array}{c}
\max _{\tau, g, B^{\prime},\left\{T_{i}\right\}_{1}^{n}} W(\tau, g)+\frac{\sum_{i} T_{i}}{m}+\beta\left[\pi v_{H}\left(B^{\prime}\right)+(1-\pi) v_{L}\left(B^{\prime}\right)\right] \\
\text { s.t. } \\
\left.\quad T_{i} \geq 0 \forall i, S\left(\tau, g, B^{\prime} ; \frac{B}{P}\right) \geq \sum_{i}^{n} T_{i}, B^{\prime} \in[\underline{B}, \bar{B}],\right] \\
\forall k B^{\prime}=\min \left\{B^{\prime}: q B^{\prime}=k\right\}
\end{array}\right]
$$

The self-interested fiscal authority's optimization problem differs only in potential transfers. If there are no transfers, the problem is identical to that of the benevolent fiscal authority hence the optimal choices are identical. If there are transfers the first 
order conditions are

$$
\begin{aligned}
\frac{n}{m} & =\frac{1-\tau^{*}}{1-\tau^{*}(1+\epsilon)} \\
\frac{n}{m} & =\frac{n A}{g^{*}} \\
B^{\prime *} & =\arg \max _{B^{\prime}}\left[\frac{q B^{\prime}}{m}+\beta\left[\pi v_{H}\left(B^{\prime}\right)+(1-\pi) v_{L}\left(B^{\prime}\right)\right]\right]
\end{aligned}
$$

The left hand side $\frac{n}{m}$ term represents the amount each individual in the governing coalition will receive as a transfer from an additional unit of revenue from every consumer. The first equation shows the marginal benefit to coalition members from additional revenue is equal to the marginal cost of raising that additional unit by distortionary taxation. The second equation displays the choice of the government to spend revenue: the marginal benefit of transfers to the governing coalition is equal to the marginal benefit from using that revenue on public good spending. The third equation chooses the optimal amount of bonds to issue to fund increased transfers versus the cost of increased bonds in the next period.

Note that $\left\{\tau^{*}, g^{*}, B^{*}\right\}$ are constants. When there are transfers the tax rate, government spending, and level of bonds will be constant. The government will raise revenue from taxes $\tau^{*}$ and bonds $B^{*}$. It will spend $g^{*}$ on the public good. Whatever revenue is left over after that spending is used to fund transfers.

The self-interested fiscal authority's problem can be written recursively and simplified to resemble that of the benevolent fiscal authority

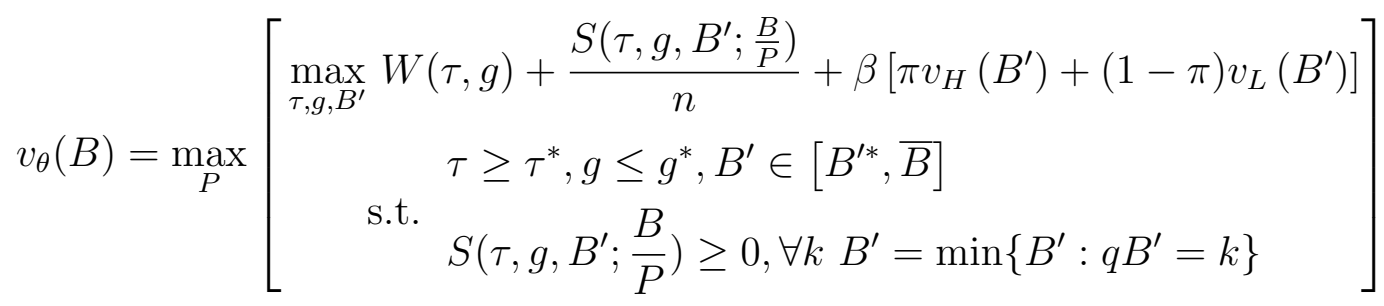

The new constraints are limits on the lowest taxes, highest government spending and least bonds. If there are transfers, these variables become stuck at the starred value and cannot go lower or higher.

We can determine when there will be transfers. If the revenue from taxes $\tau^{*}$ and bonds $B^{*}$ is sufficient to cover spending $g^{*}$ on the public good, there will be transfers. 
Thus there is a cutoff

$$
C_{\theta}=\operatorname{Rev}_{\theta}\left(\tau^{*}\right)+q B^{\prime *}-g^{*}
$$

which is the level of bonds such that $S_{\theta}\left(\tau^{*}, g^{*}, B^{\prime *} ; C_{\theta}\right)=0$. If the current level of bonds in the period is above $C_{\theta}$ there will be no revenue for transfers thus the optimization problem is identical to that of the benevolent fiscal authority. If the current level of bonds is below $C_{\theta}^{*}$ there will be revenue for transfers while taxes, public good spending and bond issuance are $\left\{\tau^{*}, g^{*}, B^{*}\right\}$ respectively.

The monetary authority chooses $P^{6}$ to maximize welfare

$$
P(B)= \begin{cases}1, & \text { if } B \leq C_{\theta} . \\ \frac{B}{C_{\theta}}, & \text { if } B>C_{\theta} .\end{cases}
$$

If the level of nominal bonds is less than the bond cutoff that means there are transfers. If the monetary authority were to increase the price level, the amount of debt the self-interested fiscal authority owed would go down. The revenue the self-interested fiscal authority had directed to bond repayment would instead go to transfers while taxes and government spending would remain constant at $\tau^{*}$ and $g^{*}$. This would not increase welfare hence the monetary authority keeps the price level constant.

If the level of nominal bonds is greater than or equal to the bond cutoff there are no transfers. The self-interested fiscal authority's optimization problem is identical to that of the benevolent fiscal authority. The monetary authority's choice is also identical: erase the real value of bonds by increasing the price level as long as the fiscal authority will use the extra revenue to decrease taxes rather than increase transfers.

\footnotetext{
${ }^{6}$ This pricing requires $C_{\theta} \geq 0$. (If $C_{\theta}=0$ the second condition would need to be $P=$ $\infty$, if $B>C_{\theta}$ ) The issue arises because the monetary authority can't change a positive level of bonds into a negative one (nor vice-versa) since $P>0 . C_{\theta}<0$ implies that even if the government accumulated a surplus there would be no transfers; a situation I consider unlikely. Also note that introducing the self-interested fiscal authority solves the indeterminacy problem that bedevils the benevolent fiscal authority's problem.
} 


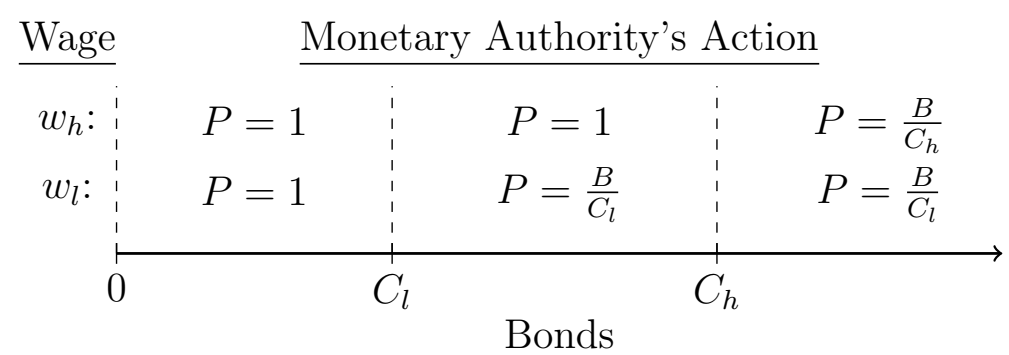

Figure 3: The Monetary Authority's Decision with a Self-Interested Fiscal Authority

Claim 3 The self-interested fiscal authority's solution is to issue $C_{h}$ bonds that raise $\beta\left(\pi C_{h}+(1-\pi) C_{l}\right)$ revenue in every period.

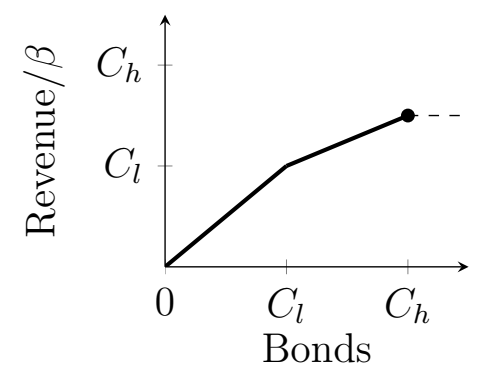

Figure 4: Revenue with a Self-Interested Fiscal Authority

The self-interested fiscal authority issues $C_{h}$ bonds because that level maximizes the amount of revenue raised while holding taxes and government spending at their starred values. Issuing more bonds raises no additional revenue because the monetary authority will inflate away those bonds no matter the wage realization. If the selfinterested fiscal authority issues less than $C_{h}$ bonds it is foregoing revenue that would be available if there is a good realization of the wage.

For all realizations of the wage and any amount of bonds taxes will be constant at $\tau^{*}$ and government spending constant at $g^{*}$. These are the lowest possible taxes and highest possible spending and thus lead to the highest possible welfare.

Price level commitment is equivalent to issuing indexed bonds: the monetary authority has no control over the real value of nominal bonds. This is similar to the situation in Barseghyan et al. (2013). To prove Proposition 2 I need to establish that 
price commitment leads to taxes and government spending that are not $\tau^{*}, g^{*}$ for at least single period.

Intuitively the self-interested fiscal authority will issue (what will be ex-post) too many bonds ${ }^{7}$ because it doesn't know the realization of tomorrow's productivity shock. If the shock is $w_{h}$ the bonds will be paid off easily and taxes and government spending will be $\tau^{*}, g^{*}$. If the shock is $w_{l}$ taxes will be higher and government spending lower in order to provide more revenue to repay the bonds.

\section{Optimal Design of Monetary, Fiscal Structure}

The monetary and fiscal structure of most modern advanced economies looks similar. A government subject to elections controls fiscal policy. A central bank independent from the voting process is tasked with controlling the price level. The vast majority of government debt is nominal.

Proposition 3 The pairing of a self-interested fiscal authority and an independent monetary authority with nominal bonds and discretionary policy is the solution to a real world constrained mechanism design problem that results in the highest welfare.

The mechanism design problem is to choose the structure of the economy to maximize welfare. This can be viewed as a constitutional design problem. There are two possibilities for the fiscal authority: benevolent or self-interested. There are two possibilities for the monetary authority: independent or not. There are two possibilities for bonds: indexed (equivalent to price level commitment) or nominal. If bonds are real control of the monetary authority is irrelevant since the monetary authority has no choices to make

Amongst the six possible combinations, the combination resulting in the highest welfare has a benevolent fiscal authority and real bonds. I ignore this combination. Dictatorships do not issue real bonds in the real world possibly due to the inability to make real contracts enforceable across regimes. Additionally, it's very hard to find a benevolent dictator.

\footnotetext{
${ }^{7}$ Specifically the self-interested fiscal authority will issue $\left(\pi C_{h}+(1-\pi) C_{l}\right)$ bonds. This amount lies in the region where there will be transfers (and $\tau^{*}, g^{*}$ ) on a good realization of $w=w_{h}$ and no transfers if $w=w_{l}$. The specific level balances the benefit of transfers today with the possibility of increased taxes tomorrow.
} 
Definition 4 A captured monetary authority is a monetary authority that is not independent. It will be controlled by the same microfounded political process as a self-interested fiscal authority. Namely it tries to maximize the utility of $m$ out of $n$ consumers. The monetary authority's $m$ coalition does not need to be composed of the same consumers in the fiscal authority's $m$ coalition.

A captured monetary will set the price level to infinity if there are any nominal bonds since this will decrease the taxes its $m$ coalition will face. See the proof of Proposition 3 in the Appendix.

Comparing the four available combinations, choosing a self-interested fiscal authority, an independent monetary authority, and nominal bonds is optimal. This is the design illustrated in Proposition 2, I briefly describe and compare the other combinations to this one below.

1. Benevolent Fiscal, Benevolent Monetary, Nominal Bonds: This combination is unable to support any nominal bonds due to the time inconsistency problem. There will be no tax smoothing.

2. Benevolent Fiscal, Captured Monetary, Nominal Bonds: This combination is unable to support any nominal bonds due to the time inconsistency problem. There will be no tax smoothing.

3. Self-Interested Fiscal, Benevolent or Captured Monetary, Indexed Bonds: This combination is explored in Proposition 2 and shown to result in lower welfare than if it featured nominal bonds.

4. Self-Interested Fiscal, Captured Monetary, Nominal Bonds: This combination is unable to support any nominal bonds due to the time inconsistency problem. There will be no tax smoothing.

Since the setup featuring a self-interested fiscal authority and an independent monetary authority with nominal bonds is welfare maximizing, it's natural we observe it in the real world. As with the choice to use nominal bonds, citizens in an original position would choose this structure; possibly by embedding it in the constitution of the state.

This analysis presupposes that nominal bonds are the only intertemporal savings instrument available. Taking one step back, it's necessary to explain why nominal 
bonds will exist instead of real bonds. There are two ways to justify nominal bonds. As shown by Proposition 2 welfare is higher with nominal bonds. If citizens in an original position, before the first period coalition is chosen, were able to vote on nominal or real bonds they would choose solely nominal.

The second way is to assign responsibility for choosing real or nominal bonds to the monetary authority. The fiscal authority chooses the amount of bonds, but the type is chosen by the monetary side. The monetary authority seeks to maximize overall utility which is is higher under nominal bonds. Hence it will insist on nominal instead of real.

\section{Monetary Unions}

Monetary unions consist of a single monetary authority and multiple fiscal authorities. The model extends to analyze monetary unions and provides insight into the crisis that has hampered the European Union. Greece's actions and current predicament are the rational outcome for a small country in a monetary union of large countries.

Proposition 4 A small country in a monetary union with large countries behaves as if it had price commitment.

The main requirement of Proposition 4 is that the central bank not respond to the fiscal actions of the small country. This is equivalent to price commitment where $P(B)=k$ for some $k$. The actions, and side effect, are the same. The monetary authority's full reaction function $P(B)$ is necessary to rein in the debt and transfers a self-interested fiscal planner would provide.

The incentives to join a monetary union are the ability to issue bonds to smooth taxes. This will result in higher welfare. While Proposition 2 shows that welfare is higher without price commitment, it also illustrates why price commitment would be lucrative to a governing coalition. A self-interested fiscal authority will issue debt to fund transfers with the hope that tomorrow will have high productivity. If instead tomorrow has low productivity, taxes will need to be punitively high to pay for the debts incurred today.

The model's description matches what has happened with Greece. After joining the Eurozone, Greek public spending and debt increased $\mathbb{8}^{6}$ Greece issued Euro denominated debt that appeared nominal. It wasn't: the ECB wouldn't change the price 
level to keep the Greek fiscal authority in line. During the good times Greece was able to repay the debt while keeping tax rates low. When the financial crisis struck Greece was unable to use inflation to erase its debt. Instead, it had to raise taxes significantly to raise the necessary revenue.

This outcome was foreseen by the designers of the Eurozone. The Maastricht Treaty had fiscal rules to constrain the constituent fiscal authorities built into it to constrain budget deficits and debt issuance. The fiscal rules were ignored by member countries large and small.

\section{Conclusion}

Price commitment is a dangerous thing. Discretionary monetary policy keeps fiscal policy in line; monetary commitment gives the fiscal authority the power to ignore monetary constraints. Counterintuitively, giving the monetary authority commitment lessens its power over the fiscal authority to the detriment of overall welfare.

This paper shows that monetary policy benefits from distorted fiscal policy. Without an explicit commitment mechanism, nominal bonds are possible only if fiscal policy is self-interested. Although the utility functions of the monetary and fiscal authorities will differ, the overall result is better for the monetary authority's goal of maximizing welfare than when they are identical.

The source of the welfare gain is a desire by the monetary authority to avoid what it views as waste. Eliminating the debt burden of a self-interested fiscal authority leads to wasteful spending. Controlling the self-interested fiscal authority also provides the justification for nominal bonds. Indexed bonds, as in the case of price level commitment, allow a self-interested fiscal authority to act without constraint. If the power to choose the type of bonds is vested in either the monetary authority or citizens, they will choose nominal bonds.

Without an independent monetary authority this structure collapses. Control of both fiscal and monetary policy decisions doesn't provide control over the expectations of citizens. The time inconsistency problem returns and nominal bonds are impossible.

\footnotetext{
${ }^{8}$ The additional transfers afforded by debt may indicate why staying in the Eurozone was associated with the elite in many countries. In the model transfers are used to enrich the governing coalition. Joining a monetary union frees funds to increase transfers thus the elite or governing coalition would be in favor of joining a union.
} 
It's in society's interest for the monetary authority to be independent from the fiscal authority.

The structure of modern economies, where fiscal decisions are controlled by a political entity and monetary decisions by an independent non-political body with nominal bonds and without price commitment, is the efficient choice. It allows some bonds to be issued, but not so many that the political distortion is able to distort optimal policy. All other combinations lead to either too high taxes or no tax smoothing.

The logic extends to monetary unions. A monetary union entails giving giving up local control of monetary decisions. If the new monetary authority is proves unresponsive to the local fiscal decisions the local self-interested fiscal authority will operate as if it has indexed debt. This means a self-interested fiscal authority will issue too much debt and suffer the consequences when bad times come as happened in the European Union.

\section{References}

Adam, Klaus and Roberto M Billi, "Monetary conservatism and fiscal policy," Journal of Monetary Economics, 2008, 55.

Aiyagari, S Rao, Albert Marcet, Thomas J Sargent, and Juha Seppälä, "Optimal Taxation without State-Contingent Debt," Journal of Political Economy, December 2002, 110 (6), 1220-1254.

Albanesi, Stefania, V V Chari, and Lawrence J Christiano, "How Severe is the Time Inconsistency Problem in Monetary Policy?," NBER Working Paper 8139, 2001.

Alvarez, Fernando, Patrick J Kehoe, and Pablo Andres Neumeyer, "The Time Consistency of Optimal Monetary and Fiscal Policies," Econometrica, March 2004, $72(2), 541-567$.

Azzimonti, Marina, Marco Battaglini, and Stephen Coate, "On the Case for a Balanced Budget Amendment to the U.S. Constitution," Princeton University, 2010.

Baron, David P and John A Ferejohn, "Bargaining in Legislatures," The American Political Science Review, December 1989, 83 (4), 1181-1206. 
Barro, Robert J, "On the determination of the public debt," Journal of Political Economy, 1979, 87 (5).

- and David B Gordon, "A Positive Theory of Monetary Policy in a Natural-Rate Model," Journal of Political Economy, November 1983, 91 (4).

Barseghyan, Levon, Marco Battaglini, and Stephen Coate, "Fiscal policy over the real business cycle: A positive theory," Journal of Economic Theory, August 2013.

Bassetto, Marco, "Fiscal theory of the price level," The New Palgrave Dictionary of Economics, 2008.

Battaglini, Marco and Stephen Coate, "A Dynamic Theory of Public Spending, Taxation, and Debt," American Economic Review, February 2008, 98 (1), 201-236.

Bohn, Henning, "Why do we have nominal government debt?," Journal of Monetary Economics, 1988, 21.

Chari, V V and Partrick J Kehoe, "Time Inconsistency and FreeRiding in a Monetary Union," Journal of Money, Credit, and Banking, 2008, 40 (7).

_ , Lawrence J Christiano, and Patrick J Kehoe, "Optimal Fiscal and Monetary Policy: Some Recent Results," Journal of Money, Credit, and Banking, 1991, 23, 519-539.

Christiano, Lawrence J and Terry J Fitzgerald, "Understanding the fiscal theory of the price level," NBER Working Paper 7668, 2000.

Díaz-Giménez, Javier, Giorgia Giovannetti, Ramon Marimon, and Pedro Teles, "Nominal debt as a burden on monetary policy," Review of Economic Dynamics, July 2008, 11 (3), 493-514.

Fischer, Stanley, "Central-bank independence revisited," American Economic Review, 1995, 85 (2), 201-206.

Kydland, Finn E and Edward C Prescott, "Rules rather than discretion: The inconsistency of optimal plans," Journal of Political Economy, 1977, 85 (3). 
Lagos, Ricardo and Randall Wright, "A Unified Framework for Monetary Theory and Policy Analysis," Journal of Political Economy, June 2005, 113 (3), 463-484.

Leeper, Eric M, "Equilibria under active and passive monetary and fiscal policies," Journal of Monetary Economics, 1991, $2 \%$.

Lucas, Robert E and Nancy L Stokey, "Optimal fiscal and monetary policy in an economy without capital," Journal of Monetary Economics, 1983, 12.

_ and _., "Money and Interest in a Cash-in-Advance Economy," Econometrica, May 1987, 55 (3), 491-513.

Martin, Fernando M, "On the joint determination of fiscal and monetary policy," Journal of Monetary Economics, 2011, 58.

Persson, Mats, Torsten Persson, and Lars E O Svensson, "Time consistency of fiscal and monetary policy," Econometrica, 1987, 55 (6).

Rogoff, Kenneth, "Can international monetary policy cooperation be counterproductive?," Journal of International Economics, 1985, 18, 199-217.

_ , "The optimal degree of commitment to an intermediate monetary target," The Quarterly Journal of Economics, 1985, 100 (4), 1169-1189.

Sargent, Thomas J and Neil Wallace, "Some unpleasant monetarist arithmetic," Federal Reserve Bank of Minneapolis Quarterly Review, May 1981, pp. 1-19.

Schmitt-Grohé, S and M Uribe, "Price level determinacy and monetary policy under a balanced-budget requirement," Journal of Monetary Economics, 2000, 45.

Stokey, Nancy L, Robert E Lucas, and Edward C Prescott, Recursive Methods in Economic Dynamics, Cambridge, MA: Harvard University Press, 1989. 


\section{A Appendix}

\section{A.1 Proof of Propositions 1 and 2}

I begin by showing Claim 2 that the benevolent fiscal authority suffers from time inconsistency and cannot issue nominal bonds. To do this it suffices to show that

$$
P(B)= \begin{cases}\frac{B}{\bar{B}}, & \text { if } B<0 \\ {[1, \infty),} & \text { if } B=0 \\ \infty, & \text { if } B>0\end{cases}
$$

Concentrating on the case of $B>0$, I take the derivative of the value function with respect to $P$ to find

$$
\frac{\partial v_{\theta}(B)}{\partial P}=\left[\frac{\epsilon \tau\left(\frac{B}{P}\right)}{1-\tau\left(\frac{B}{P}\right)(1+\epsilon)}\right] \frac{B}{n P^{2}} .
$$

This expression is always positive hence there's always a benefit to increasing the price level. To find this derivative let $P_{0}$ be the choice of $P$ that optimizes the value function $v(B)$. I will build a non-optimal function $\phi(B)$ that coincides with $v(B)$ at the optimal $P_{0}$ but is less elsewhere (and strictly concave). This will fulfill the conditions of Theorem 4.10 of Stokey et al. (1989) stating that the derivative of $\phi(B)$ is equal to that of $v(B)$ at the optimal $P_{0}$.

Choose $P$ from a neighborhood of $P_{0}$. For notational simplicity let $b=\frac{B}{P}$ and $b_{0}=\frac{B}{P_{0}}$. Define

$$
g(b)=\operatorname{Rev}\left(\tau\left(b_{0}\right)\right)+q B^{\prime}-b
$$

which is the non-optimal amount of government spending while still fulfilling debt repayment obligations. The amount of transfers will be the residual after paying back $b$ bonds.

$$
\sum_{i} T_{i}=\operatorname{Rev}\left(\tau\left(b_{0}\right)\right)+q B^{\prime}-g(b)-b
$$

Define the non-optimal utility function to be

$$
\phi(B)=W\left(\tau\left(b_{0}\right), g(b)\right)+\frac{\sum_{i} T_{i}}{n}+\beta\left[\pi v_{H}\left(B^{\prime}\right)+(1-\pi) v_{L}\left(B^{\prime}\right)\right]
$$

Expand the indirect utility and transfers terms. Note that the terms dependent on 
$P$ are the direct utility benefit of government spending, the bond holdings of the household in the current period, and transfers. Take the derivative, noting that the terms dependent on $P$ in transfers will cancel, and find

$$
\begin{aligned}
\frac{\partial \phi(B)}{\partial P} & =-\frac{B}{P^{2}}+\frac{A}{g}\left(\frac{B}{P^{2}}\right) \\
& =-\frac{B}{P^{2}}+\left[\frac{1-\tau\left(\frac{B}{P}\right)}{1-\tau\left(\frac{B}{P}\right)(1+\epsilon)}\right]\left(\frac{B}{n P^{2}}\right) \\
& =\left[\frac{\epsilon \tau\left(\frac{B}{P}\right)}{1-\tau\left(\frac{B}{P}\right)(1+\epsilon)}\right]\left(\frac{B}{n P^{2}}\right)
\end{aligned}
$$

where I've substituted in the first order condition of the fiscal authority. Taking the second derivative confirms the necessary conditions. A similar construction proves the case for $B<0$.

For a full proof that the value functions are properly defined and converge see Barseghyan et al. (2013) (specifically Propositions 1, 2 and 3). I provide a brief overview here. Showing that the self-interested fiscal authority's problem is equivalent to

$$
\begin{array}{cl}
\max _{\tau, g, B^{\prime},\left\{T_{i}\right\}_{1}^{n}} u(\tau, g)+\frac{\sum_{i} T_{i}}{m}+\beta\left[\pi v_{H}\left(B^{\prime}\right)+(1-\pi) v_{L}\left(B^{\prime}\right)\right] \\
\text { s.t. } & T_{i} \geq 0 \forall i, S\left(\tau, g, B^{\prime} ; \frac{B}{P}\right) \geq \sum_{i}^{n} T_{i}, B^{\prime} \in[\underline{B}, \bar{B}], \\
& \forall k B^{\prime}=\min \left\{B^{\prime}: q B^{\prime}=k\right\}
\end{array}
$$

follows from the bond cutoff $C_{\theta}$. If bonds are below $C_{\theta}$ the first order conditions set $\left\{\tau^{*}, g^{*}, B^{*}\right\}$ and the excess revenue is transferred to the $m$ coalition. With linear utility splitting 1 dollar of transfers amongst $m$ citizens has the same overall utility effect as splitting 1 dollar amongst $n$ citizens.

If bonds are above or equal to $C_{\theta}$ our problem is identical to benevolent fiscal policy. At $C_{\theta}$ our constraints just bind to $\left\{\tau^{*}, g^{*}, B^{*}\right\}$. Derivatives $\frac{\partial \tau}{\partial B} \geq 0, \frac{\partial g}{\partial B} \leq 0$ so for bonds above $C_{\theta}$ we have $\tau \geq \tau^{*}, g \leq g^{*}$.

To show that the value function and optimal bond level are characterized by the first order conditions I duplicate the proofs from Barseghyan et al. (2013). First 
assume the optimal bond level solves the value function given the value function. By backwards induction on period $T+1$ where the dictator is appointed it's easy to show that they will coincide in the first round. On the other hand showing that the optimal bond level solves the value function is a proof by contradiction. Namely any value other than the optimal bond level leads to lower transfers or higher taxes on the proposer. The existence of an equilibrium comes from showing the value function is a contraction for all values of bonds.

It remains to show that

$$
P(B)= \begin{cases}1, & \text { if } B \leq C_{\theta} . \\ \frac{B}{C_{\theta}}, & \text { if } B>C_{\theta} .\end{cases}
$$

I follow the same steps as with a benevolent fiscal authority. The first order condition for the monetary authority with a self-interested fiscal authority is

$$
\frac{\partial v_{\theta}(B)}{\partial P}= \begin{cases}0, & \text { if } B<C_{\theta} . \\ {\left[\frac{\epsilon \tau\left(\frac{B}{P}\right)}{1-\tau_{2}\left(\frac{B}{P}\right)(1+\epsilon)}\right] \frac{B}{n P^{2}},} & \text { if } B>C_{\theta} .\end{cases}
$$

If $\frac{B}{P} \geq C_{\theta}$ the self-interested fiscal authority's problem is identical to the benevolent fiscal authority's problem hence the derivative is equal. When $\frac{B}{P}<C_{\theta}$ the derivative can be taken directly from the definition of $v(B)$. Increasing the price level causes no change in taxes or government spending (which are pegged at $\tau^{*}, g^{*}$ ). It will redistribute income gained from the inflation tax on all $n$ consumers into transfers to the $m$ in the coalition. Because utility is transferable the overall welfare is identical.

Claim 3 says that a self-interested fiscal authority will issue $C_{h}$ bonds. Revenue from issuing bonds either lowers the current tax rate or increases transfers. Both of these result in higher utility for the self-interested fiscal authority. Hence the selfinterested fiscal authority will attempt to maximize bond revenue. This is done by issuing $C_{h}$ bonds. Bonds greater than $C_{h}$ will be inflated away, bonds less than $C_{h}$ would forego revenue if tomorrow has high productivity.

To finish the proof of Proposition 2 that discretionary monetary policy is superior to price level commitment I need to show that the tax level deviates from the minimum $\tau^{*}$ for a single period. The model with price level commitment is equivalent to a simplified version of Barseghyan et al. (2013). See the paper for an in-depth 
description of the dynamics of the model. Without a monetary authority to keep debt at the proper cutoff $C_{\theta}$, debt will exceed the cutoff, specifically it will do so in periods of low realizations of the productivity shock. A self-interested fiscal authority will attempt to fund transfers today by counting on a high realization tomorrow to fund bond repayment. When there is a low productivity shock taxes will exceed the minimum values established previously.

\section{A.2 Proof of Proposition 3}

The only new part of this proposition is that an independent monetary authority is superior to a captured monetary authority. I proceed as before to differentiate the value function with respect to $P$ to determine optimal behavior.

If the fiscal authority is benevolent, the optimal price setting of a captured monetary authority is identical to that of an independent monetary authority. Namely, decreasing the real value of bonds means taxes decline and government spending increase. The reasoning, construction of the derivative and pricing function are identical to Proposition 1. The benevolent fiscal authority will be unable to issue any nominal bonds.

If the fiscal authority is self-interested, the derivative of the self-interested monetary authority's value function with respect to $P$ is

$$
\frac{\partial v(B)}{\partial P}= \begin{cases}\left(\frac{n}{m}-1\right) \frac{B}{n P^{2}}, & \text { if } B<C_{\theta} \\ {\left[\frac{\epsilon \tau_{2}\left(\frac{B}{P}\right)}{1-\tau_{2}\left(\frac{B}{P}\right)(1+\epsilon)}\right] \frac{B}{n P^{2}},} & \text { if } B>C_{\theta} .\end{cases}
$$

The case $\frac{B}{P} \leq C_{6}{ }^{9}$ arises from the equivalence of government debt and transfers in a consumer's budget constraint: both are wealth. Receiving a transfer is identical to holding government debt. Increasing the price level decreases nominal government debt that every consumer holds. The total decrease in debt will equal the total increase in transfers to just the coalition that controls the captured monetary authority.

Independent monetary policy weighed this increase averaged across all $n$ consumers compared to the decrease in debt and saw it had no effect. (The derivative

\footnotetext{
${ }^{9}$ The value displayed for the case $\frac{B}{P} \leq C_{\theta}$ is correct if the coalition controlling the captured monetary authority is the same as the coalition controlling the self-interested fisal authority. The exact value depends on the overlap between the two coalitions. The captured monetary authority is freeing funds to be used as transfers to the self-interested fiscal authority's coalition. Since $m>n / 2$ the overlap, and thus the derivative, is guaranteed to be positive.
} 
was 0 in this region.) For captured monetary policy, those transfers aren't averaged. Increasing the price level decreases the amount the government has to repay everyone while increasing the transfers to just the coalition. It is in effect a lump sum tax on all to fund direct transfers for the coalition.

The derivative is always positive so there's always a benefit to increasing the price level,

$$
P= \begin{cases}{[1, \infty),} & \text { if } B=0 \\ \infty, & \text { if } B>0\end{cases}
$$

Hence a captured monetary authority means that no nominal bonds will be possible.

\section{A.3 Proof of Proposition 4}

Since the monetary authority is observing one country while ignoring the other this is only nominally different from the standard price level commitment case described in Proposition 2. However, it should be evident that this is identical to price level commitment. In equilibrium the observed country is following Claim 3 and issuing $C_{h}$ bonds. The shared price level will therefore be 1 on a high realization of the

productivity shock or $\frac{C_{h}}{C_{l}}$ on a low realization of the productivity shock. Both are independent from any actions taken by the non-monitored country.

\section{A.4 Brief Note on Timing}

The default timing is that the monetary authority chooses the price level before the fiscal authority chooses fiscal instruments. This timing results in a model that accurately mirrors the real world while the alternative timing does not. I take that as prima facie evidence that this is the correct choice.

The alternative timing is that the fiscal authority chooses fiscal instruments before the monetary authority. This results in no nominal bonds being used. The reasoning is that the fiscal authority has a choice at the beginning of every period to raise revenue to pay back bonds. Taxation is distortionary so the fiscal authority will never raise the revenue necessary to pay back bonds. The fiscal authority can do this because it knows that the monetary authority will raise the price level to equate revenue minus transfers and public good spending to the amount of bonds. That surplus revenue will identically be zero so the price level would need to be infinity. 


$$
P(B)= \begin{cases}\frac{B}{\operatorname{Rev}(\tau)+B^{\prime}-g-\sum_{i} T_{i}}, & \text { if } B>0, \operatorname{Rev}(\tau)+q B^{\prime}>g+\sum_{i} T_{i} . \\ \infty, & \text { if } B>0, \operatorname{Rev}(\tau)+q B^{\prime}=g+\sum_{i} T_{i} . \\ {[1, \infty),} & \text { if } B=0 .\end{cases}
$$

Essentially the fiscal authority forces the monetary authority to inflate thus nominal bonds won't be possible. In the default timing with a benevolent fiscal authority the time inconsistency problem is that the monetary authority is unable to commit thus expectations run wild. Here the time inconsistency problem is that the fiscal authority is unable to commit to raise the revenue necessary to repay bonds. 